Microbes and Environments

Vol. 12, No. 3, 75-81, 1997

\title{
Enhanced Stress Resistance at Stationary Phase of Oligotrophic Bacteria, Chromobacterium sp. Y95 and Aeromonas sp. $\mathbf{Z 0 6}$
}

\author{
Yoshio Kimura*, Nobutaka Ookubo, Hidetoshi Ozawa and Masayuki Sato \\ Department of Bioresource Science, Faculty of Agriculture, Kagawa University, \\ Miki-Cho, Kagawa 761-07, Japan
}

(Received April 24, 1997-Accepted July 16, 1997)

\begin{abstract}
Oligotrophic bacteria, Chromobacterium sp. Y95 and Aeromonas sp. Z06, can grow in 104-diluted nutrient broth $\left(1 / 10^{4} \mathrm{NB}\right)$. In the two oligotrophic bacteria, the stationary phase cultures showed enhanced heat, oxidation, and osmotic resistance as compared with cultures at exponential phase, although resistance was less marked than that of Escherichia coli. On Southern bloting analysis, Chromobacterium sp. Y95 and Aeromonas sp. Z06 genomic DNA hybridized with the sigma factor probes, RpoN-X and RpoD-4.2, and RpoD-4.2, respectively.
\end{abstract}

Key words: Stress resistance, Oligotrophic bacteria, Chromobacterium, Aeromonas

\section{Introduction}

Microorganisms are capable of growing in various extreme environments, such as under condition of thermal, acidic or osmotic stress ${ }^{3)}$. Bacteria that grow under low-nutrient conditions are known as oligotrophic bacteria ${ }^{10)}$. Kuznetsov et al. defined the oligotrophs as bacteria isolated on organic media containing between 1 and $15 \mathrm{mg}$ of $\mathrm{Cl}^{-110}$ ). Oligotrophic bacteria utilize a wide variety of carbon compounds to take advantage of whatever substrates are available in low-nutrient environments ${ }^{25)}$. We isolated oligotrophic bacteria from soil. These bacteria grew in a $10^{4}$-diluted nutrient broth $\left(1 / 10^{4} \mathrm{NB}, 0.8 \mathrm{mg}\right.$ of organic carbon per liter) with doubling times of 1.5 to 3 days, and reached final yields of 5.2 to $8.6 \times 10^{6}$ colony-forming units (CFU) per $\mathrm{ml}^{8}$.

Escherichia coli, a typical copiotrophic bacterium,

* Corresponding author; Tel: 0878-98-9674, Fax: 0878-98-7295, E-mail: kimura@ag.kagawa-u.ac.jp. did not grow under such conditions, although $E$. coli is capable of surviving various stresses ${ }^{13,23)}$. Starved or stationary $E$. coli cells are more resistant to heat shock, oxidative stress, and osmotic assault than exponential phase cells ${ }^{14,24)}$. A subunit of a putative RNA polymerase, $\sigma^{38}$ factor encoded by the $r p o S$ gene, is a regulator of central importance for gene expression during the transition to stationary phase ${ }^{6)}$. $E$. coli responds to glucose starvation by inducing about 30 proteins which confer enhanced starvation resistance ${ }^{4}$. We investigated whether stationary phase cells of two oligotrophic bacteria are more resistant to a variety of environmental assaults than those in exponential phase.

\section{Materials and Methods}

\section{Bacterial strains and growth media}

Two oligotrophic bacteria, Chromobacterium sp. Y95 and Aeromonas sp. Z06, and Escherichia coli IFO3301 were used ${ }^{8}$. Nutrient broth (NB) containing 1\% meat extract (Wako Pure Chemicals, Osaka), 1\% 
polypeptone (Wako Pure Chemicals) and $0.5 \% \mathrm{NaCl}$, pH7.0, and 50 -fold or 10000 -fold (1/50 NB or $1 / 10^{4}$ NB) diluted broth were used ${ }^{19)}$.

\section{Growth conditions}

Bacteria were cultured first in $1 / 50 \mathrm{NB}$ at $27^{\circ} \mathrm{C}$ for 1 to 3 days without agitation. One $\mathrm{ml}$ of the broth was then inoculated into $100 \mathrm{ml}$ of $1 / 50 \mathrm{NB}$ or $1 / 10^{4} \mathrm{NB}$, and cultured at $27^{\circ} \mathrm{C}$ under static conditions. Growth was measured by colony counting. Samples of $1 \mathrm{ml}$ were pipetted into sterile Petri dishes and mixed with $20 \mathrm{ml}$ of $1 / 50 \mathrm{NB}$ containing $1.5 \%$ agar. The plates were incubated at $27^{\circ} \mathrm{C}$ for 3 days.

\section{Stress resistance examination}

Oligotrophic bacteria and $E$. coli cells grown in $1 / 50$ $\mathrm{NB}$ or $1 / 10^{4} \mathrm{NB}$ at mid-logarithmic and stationary phases were harvested by centrifugation. Aliquots of cultures were diluted to ca. $1 \times 10^{6} \mathrm{cells} / \mathrm{ml}$ in the same culture medium, and $3 \mathrm{ml}$ was pipetted into $\phi 18$ test tubes and used for stress resistance assays. Control experiments with different concentrations of $\mathrm{H}_{2} \mathrm{O}_{2}$ and $\mathrm{NaCl}$, or various temperatures and exposure periods established that these adaptation doses conferred maximal resistance to challenge by their respective stresses. Levels of stress for $E$. coli were determined by the method described previously ${ }^{14,21)}$. In the oligotrophic bacteria, the levels of stress were set so that stationary phase cell survival was at least several percent. The levels of stress are indicated in each figure legend. Percent viability was determined by col- ony counting on $1 / 50$ NB plates, with $100 \%$ viability representing the colony counts of the cultures just prior to the stress tests.

\section{Isolation of genomic DNA}

E. coli and oligotrophic bacteria were grown in 2 liters of $1 / 50$ NB. Total genomic DNA was isolated by the method of Avery and Kaiser ${ }^{1}$. Cells were lysed with TNE buffer (10 mM Tris-HCl, pH7.5, $1 \mathrm{mM}$ EDTA-2Na, and $0.2 \mathrm{M} \mathrm{NaCl}$ ) containing $1 \% \mathrm{SDS}$ at $60^{\circ} \mathrm{C}$ for $10 \mathrm{~min}$. After three extractions with phenol, the genomic DNA was precipitated with ethanol .

\section{Southern hybridization with $\sigma$ factor probes}

Aliquots of about $5 \mu \mathrm{g}$ of genomic DNA were digested completely with suitable restriction endonucleases, electrophoresed in $0.7 \%$ agarose gels, and transferred onto nylon membranes, GeneScreen Plus (NEN Research Products, USA). Hybridization was carried out using a hybridization buffer $(0.5 \mathrm{M}$ sodium phosphate buffer, $\mathrm{pH} 7.2,7 \% \mathrm{SDS}$, and $1 \mathrm{mM}$ EDTA-2Na) for $12 \mathrm{~h}$ at $52^{\circ} \mathrm{C}$ with digoxigenin (DIG)-11-dUTP labeled probes. The sequences of the oligonucleotide probes are shown in Table 1. After hybridization, the membranes were washed three times in $40 \mathrm{mM}$ sodium phosphate buffer ( $\mathrm{pH}$ 7.2) containing $1 \%$ SDS at $52^{\circ} \mathrm{C}$ for $40 \mathrm{~min}$. Hybridizing DNA bands were detected using a DIG DNA detection kit (Boehringer Mannheim Biochemicals, Mannheim, Germany).

Table 1. Sequences of oligonucleotide probes used for Southern analysis

\begin{tabular}{|c|c|}
\hline RpoD-4.2 (20 mer $)^{\mathrm{a}}$ & TGRCGRATACGYTCRCGRGT \\
\hline RpoH-2.4 (23 mer) $)^{b}$ & GTYGCRACTTTRACRATRCGCCA \\
\hline RpoN-X (26 mer) ${ }^{c}$ & GGRCTRTGCAGRTAYTTYTGCGTGGT \\
\hline FliA-2.4 $(20 \text { mer })^{d}$ & ACSGASCSGSGSACCCARTC \\
\hline FliA-4.2 (20 mer $)^{\mathrm{d}}$ & TGGATCTGSSASACSCGSSA \\
\hline \multicolumn{2}{|c|}{$\begin{array}{l}\text { The sequence of the RpoD-4.2 probe was highly conserved in } \sigma^{70} \text { family }{ }^{12)} \text {. } \\
\text { b Heat shock sigmas from } E \text {. coli } \mathrm{RpoH}\left(\sigma^{32}\right) \text { and Citrobacter freundii } \mathrm{HtpR} \text { have con- } \\
\text { sensus sequences in region } 2.4^{12)} \text {. } \\
\text { c RpoN-X probe was designed from conserved amino acid sequences of } E \text {. coli RpoN, } \\
\text { S. typhimurium NtrA and } K \text {. pneumoniae } \mathrm{NtrA}^{16,17,20)} \text {. } \\
\text { d FliA-2.4 and }-4.2 \text { were designed from Salmonella typhimurium } \text { FliA }^{12,18)} \text {. }\end{array}$} \\
\hline
\end{tabular}




\section{Results}

\section{Growth of oligotrophic bacteria}

The optimized culture medium for the growth of the two oligotrophic bacteria was $1 / 25$ to $1 / 50 \mathrm{NB}$, while these strains did not grow on $1 / 5 \mathrm{NB}^{8)}$. Figure 1 shows the growth curves of $E$. coli and the oligotrophic bacteria Chromobacterium sp. Y95 and Aeromonas sp. Z06 in $1 / 50 \mathrm{NB}$ and $1 / 10^{4} \mathrm{NB}$. In $1 / 50 \mathrm{NB}$, Chromobacterium sp. Y95, Aeromonas sp. Z06 and E. coli entered stationary phase at $48 \mathrm{~h}, 72 \mathrm{~h}$, and $12 \mathrm{~h}$, respectively. The optical densities of the oligotrophic bacteria at stationary phase were about 2-fold higher than that of $E$. coli. In $1 / 10^{4} \mathrm{NB}$, the oligotrophic bacteria reached
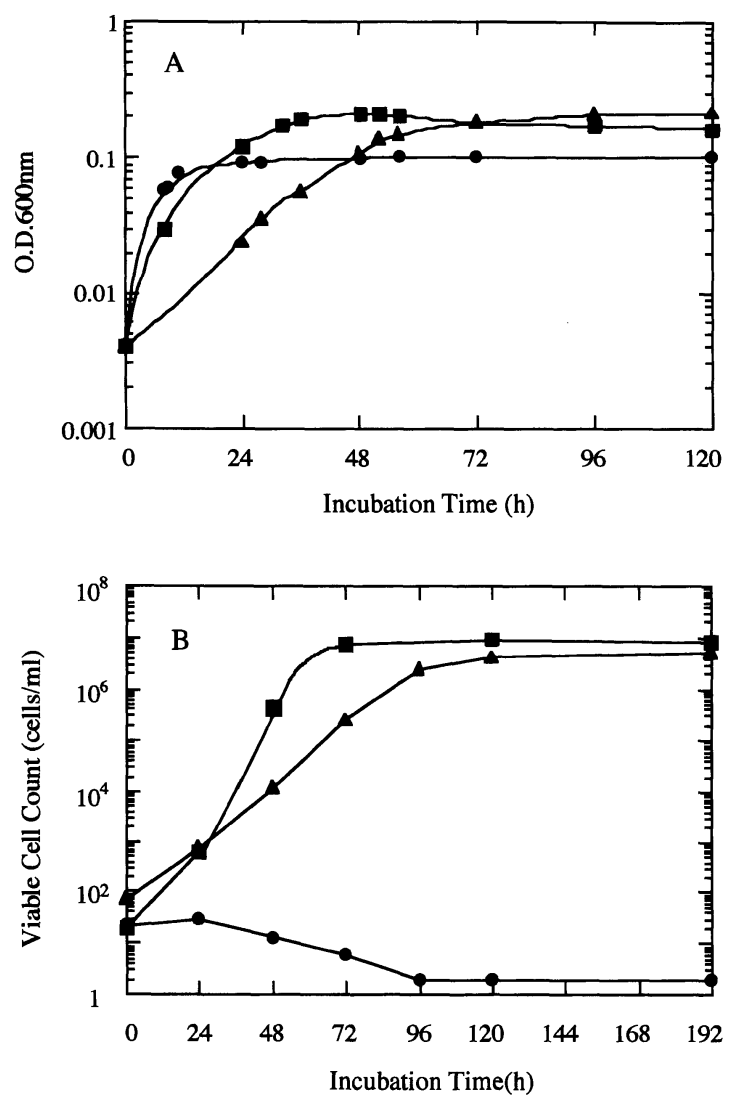

Fig. 1. Time course of growth of Chromobacterium sp. Y95, Aeromonas sp. Z06, and E. coli on $1 / 50 \mathrm{NB}$ (A) and $1 / 10^{4}$ NB (B).

Chromobacterium sp. Y95 (ם), Aeromonas sp. Z06 (A), and $E$. coli $(\mathbf{O})$. stationary phase about $24 \mathrm{~h}$ later than in $1 / 50 \mathrm{NB}$ cultures. The cell density of the oligotrophic bacteria in $1 / 10^{4} \mathrm{NB}$ increased by about $10^{5}$ fold during 4 days of cultivation, and reached final yields of 5 to $8 \times 10^{6} \mathrm{col}-$ ony-forming units (CFU) per ml. E. coli did not multiply in $1 / 10^{4} \mathrm{NB}$.

\section{Thermal and heat-induced thermal resistance}

Aliquots of E. coli, Chromobacterium sp. Y95 and Aeromonas sp. Z06, cultured to mid-logarithmic and stationary phase on $1 / 50 \mathrm{NB}$ and $1 / 10^{4} \mathrm{NB}$, were subjected to thermal stress. Stationary cells of the oligotrophic bacteria were more resistant to high tem-

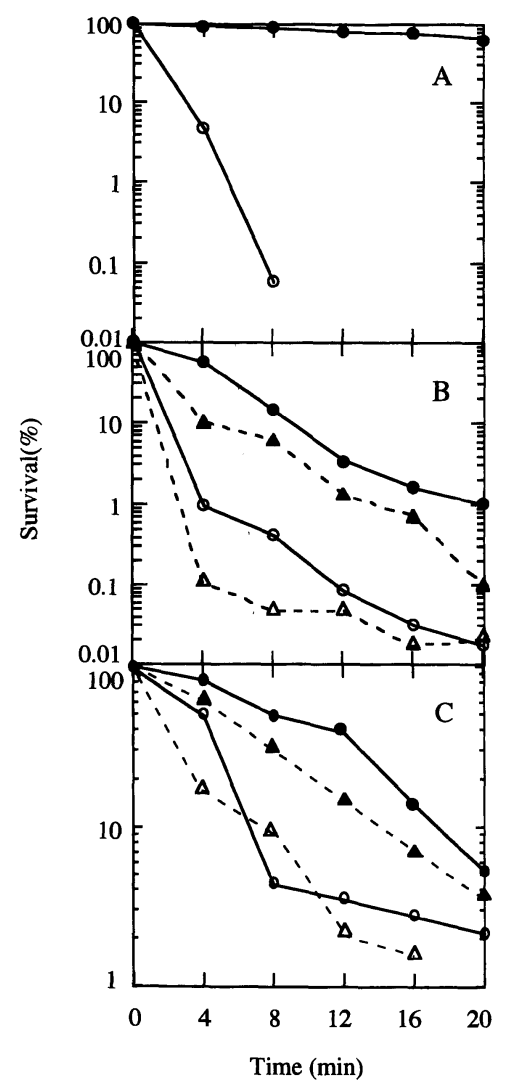

Fig. 2. Resistance to heat shock of E. coli, Chromobacterium sp. Y95, and Aeromonas sp. Z06.

Exponential $(\bigcirc$ or $\triangle$ ) and stationary $(O$ or $\boldsymbol{\Delta})$ phase cells were prepared from $1 / 50 \mathrm{NB}$ (solid lines) and $1 / 10^{4} \mathrm{NB}$ cultures (dashed lines). E. coli (A) was challenged at $52^{\circ} \mathrm{C}$, and Chromobacterium sp. Y95 (B) and Aeromonas sp. Z06 (C) were challenged at $47^{\circ} \mathrm{C}$. 
perature $\left(47^{\circ} \mathrm{C}\right)$ than those in exponential phase (Fig. 2). As shown in Fig. 2, after a 4-min challenge at $47^{\circ} \mathrm{C}, 60 \%$ of stationary phase Chromobacterium sp. Y 95 cells on $1 / 50 \mathrm{NB}$ retained viability, while viability of those in log phase was only $0.9 \%$. Stationary cells of $1 / 10^{4} \mathrm{NB}$ cultures also showed thermal resistance.

The log phase cells of Chromobacterium sp. Y95 developed thermal resistance following exposure to $37^{\circ} \mathrm{C}$ for $1 \mathrm{~h}$. The pre-heated log phase cells remained $18 \%$ viable after a 4 -min challenge at $47^{\circ} \mathrm{C}$ (Fig. 3). This viability was about 20 -fold higher than that of non-pre-heated log phase cells.

In $E$. coli, stationary cells exhibited marked resistance to heat shock, compared with those at exponential phase (Fig. 2). Also, exponential phase cells exhibited markedly enhanced survival at $52^{\circ} \mathrm{C}$ following prior exposure to $39^{\circ} \mathrm{C}$ for $30 \mathrm{~min}$ (Fig. 3).

\section{Resistance to oxidative and osmotic shock}

Stationary cells of the oligotrophic bacteria were

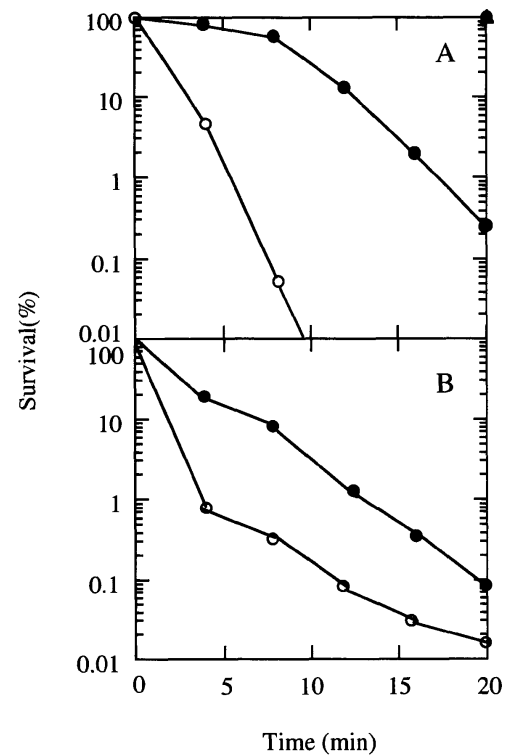

Fig. 3. Heat-induced thermal resistance of $E$. coli and Chromobacterium sp. Y95.

Aliquots of exponential cultures were untreated $(\bigcirc)$ or preheated $(O)$ before thermal challenge and tested for viability. E. coli cells (A) were pre-heated at $39^{\circ} \mathrm{C}$ for $30 \mathrm{~min}$ before challenge at $52^{\circ} \mathrm{C}$. Chromobacterium sp. Y95 cells (B) were pre-heated at $37^{\circ} \mathrm{C}$ for $1 \mathrm{~h}$ before heating at $47^{\circ} \mathrm{C}$. also more resistant to challenge with $\mathrm{H}_{2} \mathrm{O}_{2}$ and osmotic shock than those in exponential phase (Fig. 4 and 5). Stationary cells of both $1 / 50 \mathrm{NB}$ and $1 / 10^{4}$ NB cultures showed resistance to osmotic or $\mathrm{H}_{2} \mathrm{O}_{2}$ stress, although this resistance was less marked than that of E. coli. Also, the $\mathrm{NaCl}$ and $\mathrm{H}_{2} \mathrm{O}_{2}$ concentrations at which stress was induced were low compared to $E$. coli, indicating that the oligotrophic bacteria were susceptible to low levels of stress. For example, if stress levels for $E$. coli were loaded, the oligotrophic bacteria died out completely. Although the stationary cells of the oligotrophic cultures were less resistant than those of $E$. coli, they showed enhanced resistance

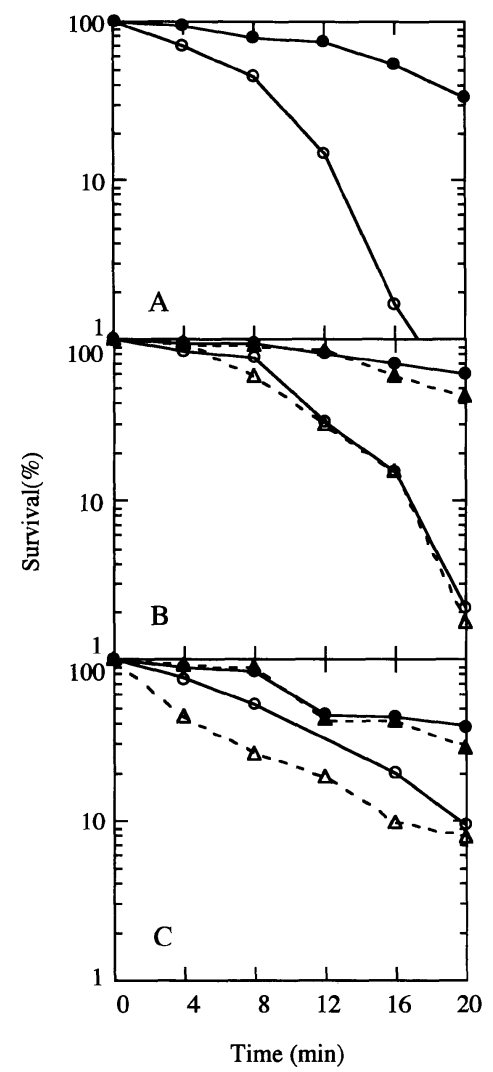

Fig. 4. Oxidative resistance of exponential and stationary phase cells.

Exponential ( $\bigcirc$ or $\triangle$ ) and stationary $(O$ or $\Delta$ ) phase cells were prepared from $1 / 50 \mathrm{NB}$ culture (solid lines) and $1 / 10^{4}$ NB culture (dashed lines). E. coli (A), Chromobacterium sp. Y95 (B), and Aeromonas sp. Z06 (C) were challenged with $50 \mathrm{mM}, 2.0 \mathrm{mM}$, and $0.8 \mathrm{mM} \mathrm{H}_{2} \mathrm{O}_{2}$, respectively. 


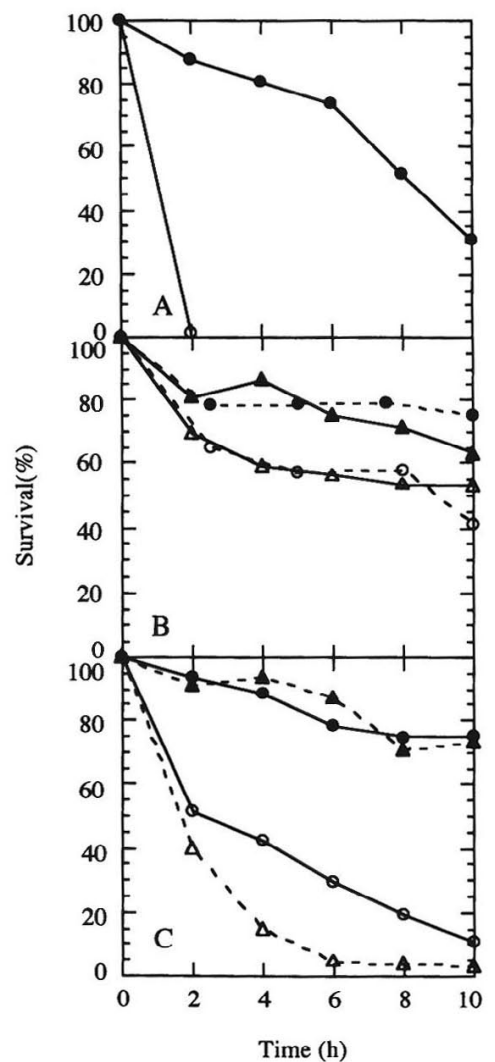

Fig. 5. Osmotic resistance of exponential and stationary phase cells.

Exponential ( $\bigcirc$ or $\Delta$ ) and stationary ( or $\Delta$ ) phase cells were prepared from $1 / 50 \mathrm{NB}$ (solid lines) and $1 / 10^{4} \mathrm{NB}$ cultures (dashed lines). E. coli (A), Chromobacterium sp. Y95 (B), and Aeromonas sp. Z06 (C) were challenged with 2.4 $\mathrm{M}, 0.03 \mathrm{M}$, and $0.2 \mathrm{M} \mathrm{NaCl}$, respectively.

to heat, osmotic, and oxidative stresses as compared with the respective mid-logarithmic phase cells.

\section{Southern bloting analysis using sigma factor probes}

Bacteria synthesize a number of different sigma factors which serve to mediate differential gene expression under a variety of conditions ${ }^{7,26)}$. As shown in Figure 6, the RpoD-4.2 probe hybridized with Chromobacterium sp. Y95 and Aeromonas sp. Z06 genomic DNA. Most genes expressed in exponentially growing cells are transcribed by the $r p o D$ gene product, holoenzyme $\mathrm{E} \sigma^{70}$. Region 4.2 of $\sigma^{70}$ is highly conserved among the primary sigma factors, and par-

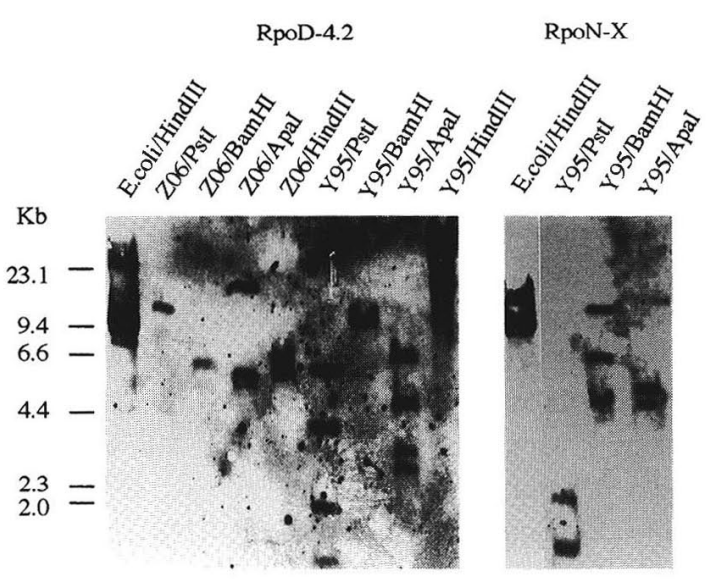

Fig. 6. Southern bloting analysis of the genomic DNA from E. coli, Chromobacterium sp. Y95, and Aeromonas sp. Z06 with RpoD-4.2 and RpoN-X probes.

ticipates in recognition of the -35 promoter sequence ${ }^{12)}$.

Chromobacterium sp. Y95 genomic DNA also hybridized with the RpoN-X probe (Fig. 6). The rpoN gene encodes $\sigma^{54}$, which is required for transcription of genes expressed depending on the availability of nitrogen sources ${ }^{15}$. Structurally, $\sigma^{54}$ is different from other $\sigma$ subunits, lacking most of the conserved sigma domains.

The other probes, RpoH and FliA, did not hybridize with genomic DNA of either oligotrophic bacterium $^{9,11,18)}$. The results of multiple sequence alignment of sigma factors genes suggested that many of these factors form a homologous protein family ${ }^{2,5)}$. Four general regions of similarity have been defined, and most bacterial sigma factors share at least two of these conserved regions. E. coli RpoS and RpoH, and Citrobacter freundii $\mathrm{HtpR}$ play a role in starvation-induced oxidative and heat resistance, and contain sequences similar to the rpoD-4.2 probe ${ }^{12,17)}$.

\section{Discussion}

In natural environments, bacteria often encounter conditions inappropriate for growth. Many bacteria have evolved highly sophisticated mechanisms to survive under such conditions. During starvation, E. coli 
cells decrease their overall metabolic rate and proceed to a more resistant state ${ }^{23)}$. E. coli recognizes $1 / 10^{4}$ NB medium as inappropriate propitious for growth, and the adenylate energy charge was dropped to about 0.5 after 72 h of cultivation ${ }^{8}$. Starved $E$. coli cells can develop multiple stress resistance and survive long periods of starvation. After 60 days of culture in ultrapure water, $9 \%$ of $E$. coli cells retained viability ${ }^{8}$.

We isolated oligotrophic bacteria, which were tentatively defined as bateria which multiplied at least 10fold over 3 days of culture in $1 / 10^{4} \mathrm{NB}$ when inoculated at about $10^{3}$ cells $/ \mathrm{ml}$, from soil ${ }^{8}$. These strains, $\mathrm{Y} 95$ and Z06, also grew in $1 / 10^{5} \mathrm{NB}$, and reached about 1 to $10 \times 10^{5}$ cells $/ \mathrm{ml}$ after 3 days of cultivation (data not shown). The length of the Y95 cells grown in $1 / 10^{4} \mathrm{NB}$ were 20 to $30 \%$ shorter than that of cells grown in $1 / 50 \mathrm{NB}^{8}$. In stationary phase cells, the two oligotrophic bacteria grown in $1 / 10^{4} \mathrm{NB}$ exhibited enhanced resistance compared with those in exponential phase. These observations indicated that the two oligotrophic bacteria retained the ability to multiply and showed enhanced stress resistance under lownutrient conditions. To adapt to a low-nutrient soil environment, these features are advantageous for the oligotrophic bacteria. However, the two oligotrophic bacteria were more susceptible to lower concentrations of $\mathrm{NaCl}$ or $\mathrm{H}_{2} \mathrm{O}_{2}$ compared with $E$. coli. Although $E$. coli did not multiply in $1 / 10^{4} \mathrm{NB}$, this bacterium showed a strong capacity to adapt to various stresses.

In eubacteria, sigma factors are transcription factors that operate global switches in gene expression by conferring promoter-specific transcription initiation on bacterial RNA polymerase ${ }^{5}$. Stress protection is controlled by these sigma factors which are expressed in response to various stress conditions. On Southern blots, Chromobacterium sp. Y95 and Aeromonas sp. Z06 genomic DNA hybridized with the sigma factor probes, RpoN-X and RpoD-4.2, and RpoD-4.2, respectively, and multiple hybridizing bands were seen on the blots. These results suggest that there is a family of sigma factors which regulate various mechanisms of stress resistance in the two oligotrophic bacteria.

\section{References}

1) Avery, L. and D. Kaiser. 1983. In situ transposon replacement and isolation of a spontaneous tandem duplication. Mol. Gen. Genet. 191: 99-109.

2) Fredrick, K. and J. D. Helmann. 1994. Dual chemotaxis signaling pathways in Bacillus subtilis: a $\sigma^{\mathrm{D}}$-dependent gene encodes a novel protein with both CheW and CheY homologous domains. J. Bacteriol. 176: 2727-2735.

3) Fry, J. C. 1990. In Microbiology of extreme environments. ed. by C. Edwards. Open University Press, Milton Keynes.

4) Groat, R. G., J. E. Schultz, E. Zychlinsky, A. Bockman, and A. Matin. 1986. Starvation proteins in Escherichia coli: Kinetics of synthesis and role in starvation survival. J. Bacteriol. 168: 486-493.

5) Helmann, J. D. and M. J. Chamberlin. 1988. Structure and function of bacterial sigma factors. Ann. Rev. Biochem. 57: 839-872.

6) Hengge-Aronis, R. 1993. Survival of hunger and stress: The role of rpoS in early stationary phase gene regulation in E. coli. Cell 72: 165-168.

7) Ishihama, A. 1993. Protein-protein communication within the transcription apparatus. J. Bacteriol. 175: 2483-2489.

8) Kimura, Y., Y. Ueno, K. Kajikawa, T. Nakamura and M. Sato. 1995. Physiological characteristics of three oligotrophic soil bacteria, Aeromonas sp. Y26, Aeromonas sp. Z06, and Chromobacterium sp. Y95, in low concentration of nutrient broth. Bul. Jpn. Soc. Microb. Ecol. 10: 21-29.

9) Kutsukake, K., S. Iyoda, K. Ohnishi and T. Iino. 1994. Genetic and molecular analyses of the interaction between the flagellum-specific sigma and antisigma factors in Salmonella typhimurium. EMBO J. 13: 4568-4576.

10) Kuznetsov, S. I., G. A. Dubinina and N. A. Lapteva. 1979. Biology of oligotrophic bacteria. Annu. Rev. Microbiol. 33: 377-387.

11) Landick, R., V. Vaughan, E. T. Lau, R. VanBogelen, J. W. Erickson and F. C. Neidhardt. 1984. Nucleotide sequence of the heat-shock regulatory gene of Escherichia coli suggests its protein product may be a transcription factor. Cell 38: 175-182.

12) Lonetto, M., M. Gribskov and C. A. Gross. 1992. The $\sigma^{70}$ family: Sequence conservation and evolutionary relationships. J. Bacteriol. 174: 3843-3849.

13) Matin, A., E. A. Auger, P. H. Blum, and J. E. Schultz. 1989. Genetic basis of starvation survival in nondifferentiating bacteria. Annu. Rev. Microbiol. 43: 293-316.

14) Mccann, M. P., J. P. Kidwell and A. Matin. 1991. The putative s factor KatF has a central role in development of starvation-mediated general resistance in 
Escherichia coli. J. Bacteriol. 173: 4188-4194.

15) Merrick, M. 1993. In a class of its own-the RNA polymerase sigma factor $\sigma^{54}\left(\sigma^{\mathrm{N}}\right)$. Mol. Microbiol. 10: 903-909.

16) Merrick, M. and J. Gibbins. 1985. The nucleotide sequence of the nitrogen-regulation gene ntrA of Klebsiella pneumoniae and comparison with conserved features in bacterial RNA polymerase sigma factors. Nucleic Acids Res. 13: 7607-7620.

17) Mulvey, M. R. and P. C. Loewen. 1989. Nucleotide sequence of katF of Escherichia coli suggests that katF protein is a novel $\sigma^{\mathrm{N}}$ transcription factor. Nucleic Acids Res. 17: 9979-9991.

18) Ohnishi, K., K. Kutsukake, H. Suzuki and T. Iino. 1990. Gene fliA encodes an alternate sigma factor specific for flagellar operons in Salmonella typhimurium. Mol. Gen. Genet. 221: 139-147.

19) Ohta, H. and T. Hattori. 1980. Bacteria sensitive to nutrient broth medium in terrestrial environments. Soil Sci. Plant Nutr. 26: 99-107.

20) Popham, D., J. Keener and S. Kustu. 1991. Purification of the alternative $\sigma$ factor, $\sigma^{54}$, from Salmonella typhimurium and characterization of $\sigma^{54}$-holoenzyme. J. Bio. Chem. 266: 19510-19518.

21) Sammartano, J. L., W. R. Tuveson and Davenport,
R. 1986. Control of sensitivity to inactivation by $\mathrm{H}_{2}$ $\mathrm{O}_{2}$ and broad-spectrum near-UV radiation by the Escherichia coli katF locus. J. Bacteriol. 68: 13-21.

22) Sasse-Dwight, S. and J. D. Gralla. 1990. Role of eukaryotic-type functional domains found in the prokaryotic enhancer receptor factor $\sigma^{54}$. Cell 62 : 945-954.

23) Siegele, D. A. and R. Kolter. 1992. Life after log. J. Bacteriol. 174: 345-348.

24) Tanaka, K., Y. Takayanagi, N. Fujita, A. Ishihama and H. Takahashi. 1993. Heterogeneity of the principal $\sigma$ factor in Escherichia coli: The rpoS gene product, $\sigma^{38}$, is a second principal s factor of RNA polymerase in stationary-phase Escherichia coli. Proc. Natl. Acad. Sci. USA. 90: 3511-3515.

25) Van der Kooij, D., J. P. Oranje and W. A. M. Hijne. 1982. Growth of Pseudomonas aeruginosa in tap water in relation to utilization of substrates at concentrations of a few micrograms per litter. Appl. Environ. Microbiol. 44: 1086-1095.

26) Weichart, D., R. Lange, N. Henneberg and R. Hengge-Aronis. 1993. Identification and characterization of stationary phase-inducible genes in Escherichia coli. Mol. Microbiol. 10: 407-420. 